\title{
KONCEPT CÍRKEVNÍHO DOMU A LITURGICKÉ SÍNĚ V MYŠLENÍ MIROSLAVA KOUŘILA V DOBOVÉM KONTEXTU CÍRKVE ČESKOSLOVENSKÉ
}

\author{
PAVEL KOLÁ Ř
}

\section{ABSTRACT \\ Concepts of the church community house and liturgical space in the work of Miroslav Kouril within the context of the Czechoslovak Church}

Czechoslovak Church has not yet been a subject of a detailed study. Recent research has dealt mostly with particular churches built by important Czech modernist architects (Gočár, Janák, Víšek) or with periods of development of church architecture in the Czechoslovak Church. This study presents concepts of the church community house and liturgical space in the work of Miroslav Kouril, who was an important Czech avant-garde scenographer and church architect in the 1930s and 1940s. These concepts are interpreted within the context of continual church discussions on various issues related to church architecture in the Czechoslovak church. Particular attention is paid to the leading principles proposed by Kouřil as guidelines for building a liturgical space, namely the liturgical hall as a fundamental, unified and undivided space within the church community house; the centrality of the liturgical table; and the installation of the baptistery with living water.

\section{Key words}

Modernist church architecture; Liturgical space; Church community house; Miroslav Kouřil; Czechoslovak church

DOI: $10.14712 / 23363398.2018 .48$

$\mathrm{T}$ eologické a stavebně-architektonické otázky spojené s problematikou liturgického prostoru a sakrálních staveb, pro které se užívá výraz „sbor“, nepatří v tradici Církve československé husitské k tématům, jimž je věnována souvislá odborná pozornost. V současné době 
jsou diskutovány spíše v uzavřeném okruhu bezprostředně zainteresovaných osob vždy s ohledem na praktické potřeby vytvoření nebo adaptace prostoru pro slavení liturgie, popř. stavby nového sboru. ${ }^{1}$ Poslední ucelenou teologickou reflexí liturgického prostoru v kontextu husitské teologie Církve československé husitské tak zůstávají texty Otto Rutrleho. ${ }^{2} \mathrm{~S}$ uceleným promýšlením této tematiky se nesetkáme ani v prvních dekádách života Církve československé, pro které bylo příznačné úsilí o výstavbu nových sborů, jež měly představovat charakteristický výraz sebepojetí Církve československé. ${ }^{3}$ Pokud byl liturgický prostor tematizován, pak zpravidla ve formě zadání architektonické soutěže, církevních směrnic pro výstavbu a adaptaci sborů nebo kratších časopiseckých příspěvků. Nejvýrazněji do veřejné diskuze o teologicko-architektonických zásadách pro výstavbu nových sborů a adaptaci stávajících sborových staveb ${ }^{4}$ zasáhl publikováním svých kratších studií, článků a komentářů ve 30. a 40. letech minulého století avantgardní scénograf a architekt Miroslav Kouřil.

Sakrální architektuře Církve československé doposud nebyla věnována samostatná monografie. Dosavadní stav bádání stručně shrnula a zhodnotila Amáta M. Wenzlová. ${ }^{5}$ Ve své studii přehledně periodizovala sledovaný úsek let 1920 až 1950 a jednotlivá období charakterizovala s ohledem na typologii realizovaných staveb, na důležité církevní dokumenty, které měly výstavbu nových sborů regulovat, i na postavy architektů či církevních pracovníků, kteří se podíleli na veřejné diskuzi o stávající a budoucí sakrální architektuře Církve československé. Poměrně významnou roli v těchto diskuzích ve druhé polovině 30 . let a v první polovině let 40. připisuje Miroslavu Kouřilovi. Ačkoliv si za

1 Např. vznik a otevření Husovy modlitebny v rámci obnoveného Památníku Mistra Jana Husa, resp. Centra Mistra Jana Husa v Husinci v roce 2015 nebo výstavba nového sboru po požáru v Mirovicích.

2 Srov. Otto Rutrle - Zdeněk Trtík. Vzhůru srdce: výklad bohoslužby církve československé husitské v duchu a pravdě. 1. vyd. Praha: Ústřední církevní nakladatelství 1953; Otto Rutrle. Liturgika. II. díl. 1. vyd. Praha: Ústřední církevní nakladatelství 1954.

3 Církev československá je původní název Církve československé husitské, rozšiřený sněmovním usnesením roku 1971. V době protektorátu Čechy a Morava nesla označení Církev českomoravská.

4 Otázka adaptace stávajících prostorů a staveb se stala aktuální zejména po 2. světové válce, kdy Církev československá po deportaci německého obyvatelstva převzala od čs. státu některé kostely $\mathrm{v}$ Sudetech, později také synagogy.

5 Srov. Amáta M. Wenzlová. Sakrální architektura Církve československé husitské vývoj a utváření v počátečním období (1920-1950). In: Walerian Bugel a kolektiv. Liturgická a eklesiální pluralita na územi Československa v první poloviné 20. století. 1. vyd. Olomouc: Univerzita Palackého v Olomouci 2011, s. 159-191. 
jedno z hlavních metodických hledisek své studie stanovila otázku „odrazu nově se utvářející liturgie, liturgiky a teologie vůbec v liturgických stavbách Církve československé“ ${ }^{6}$ přehledový charakter příspěvku jí nedovolil toto metodické hledisko rozvinout. Chceme se o to pokusit v následné prezentaci pojetí liturgického prostoru a stavby sboru v myšlení Miroslava Kouřila, zasazeném do dobového kontextu Církve československé.

\section{Pojetí liturgického prostoru v počátečním období Církve československé}

Teologická východiska a zásady pro tvorbu liturgického prostoru a výstavbu sborů v Církvi československé položily dva liturgické referáty, přednesené a přijaté na prvních dvou oficiálních celocírkevních shromážděních nově založené církve.

\subsection{První valný sjezd (1921) a Alois Tuháček}

První z nich přednesl na 1. valném sjezdu Československé církve v Praze roku 1921 Alois Tuháček. ${ }^{7}$ Deklaroval v něm úzký vztah mezi dogmatikou a liturgií, kterou pokládal za specifický zpo̊sob vyjádření obsahu víry. Základní formou bohoslužebného života nové církve má zůstat „liturgie“, jejímž středem bude „mešní obět" a půdorysem, na kterém se má utvářet postupně její podoba, tradiční struktura post-tridentského římského ordinis missae. Tuháček prosazoval v referátu důslednou vernakularizaci bohoslužby, hlasité pronášení (recitace či zpěv) liturgických textů jak předsedajícím (duchovním), tak i k bohoslužbě shromážděným místním společenstvím církve (obcí), přeformulování převzatých římských mešních modliteb tak, aby bylo zřejmé, že jsou modlitbami celého společenství, a v neposlední řadě obnovu „kazatelského úřadu“ v rámci liturgického slavení. Základní principy, které mají utvářet bohoslužebnou praxi nové církve, můžeme formulovat následovně: liturgie je aktem celého společenství, ve kterém specifická liturgická služba náleží těm, kdo přijali svátostné kněžství; komuniální charakter bohoslužby spoluutváří a reprezentuje důsledná vernakularizace liturgických textů, jejich pronášení jménem celé obce,

Wenzlová. Sakrálni architektura, s. 160.

Srov. Alois Tuháček. Liturgie. In: Valný sjezd Církve československé konaný v sobotu a v nedéli 8. a 9. ledna 1921 v Praze (těsnopisecký zápis). Praha: Nákladem církve Československé 1921, s. 51-66. 
hlasitý přednes a dialogická, responsivní forma některých z nich; centrální místo eucharistie a služby slova v rámci liturgie.

\subsection{První ŕádný snèm (1924) a František Kalous}

O detailnější rozpracování těchto zásad a jejich aplikaci na velmi různorodou soudobou liturgickou praxi nové církve ${ }^{8}$ se pokusil František Kalous v návrhu Řádu bohoslužebného, předloženém na 1. řádném sněmu Církve československé v Praze roku 1924. ${ }^{9}$ Jedná se o poměrně propracovaný návrh, jehož součástí je i téma liturgického prostoru s důrazem na dispozici a vybavení interiéru. V textu je F. Kalousem mimo jiné stvrzeno základní postavení liturgie (mše) v celku duchovního života církve. Návrh Liturgie, vypracovaný a církevní veřejnosti v letech 1922-1924 postupně představený Karlem Farským, je předložen jako závazný ordo pro slavení bohoslužby s večeří Páně. Bohoslužebný řád dále specifikuje „účast duchovního“ a „účast lidu“ při bohoslužbě. Předsedající má liturgii vést zpravidla bez spoluúčasti jiných duchovních či služebníků, s tváří trvale obrácenou ke shromážděné obci. Pokud z nějakého důvodu nemůže všechny, pak alespoň ty nejpodstatnější liturgické texty má pronášet zřetelně a nahlas. Gesta a symbolická jednání, která mu příslušejí, tj. znamení kříže, modlitební a žehnací gesta, symbolické jednání s kalichem vína a s chlebem, mají být uměřená, zřetelná a viditelná všemi přítomnými. Základním liturgickým postojem duchovního je stání, které může přejít v mírné sklonění hlavy. Řád nepředpokládá ani nenavrhuje žádnou formální podobu liturgického pohybu v prostoru, jmenovitě průvod. Účast lidu je spatřována ve sborovém zpěvu, ve sborových odpovědích předsedajícímu v responsivních částech liturgie, v zachovávání „posvátného ticha“, v pozorném naslouchání předsednickým modlitbám i čtením z Písma a ve společném zaujímání náležitého liturgického postoje, tj. stání nebo sezení. František Kalous pak pro liturgické čtení z Písma podporuje zavedení lekcionáře rozvrženého do čtyřletého cyklu.

Tématu liturgického prostoru se řád věnuje $\mathrm{v}$ páté části. ${ }^{10}$ Liturgickým prostorem, resp. bohoslužebným místem se stává kterékoliv místo,

\footnotetext{
8 Srov. Miroslav Kanák. Liturgický projev církve čm. v historickém přehledu a vývoji. Náboženská revue 14 (1942), s. 27-32, 97-103, 167-176, 208-217.

9 Srov. František Kalous. Řád bohoslužebný. In: Zpráva o I. rádném snému církve Československé konaném ve dnech 29. a 30. srpna 1924 v Praze-Smichové. Praha: Nákladem ústřední rady CČS 1924, s. 126-152.

10 Srov. Kalous. Řád bohoslužebný, s. 144-147.
} 
na kterém se společenství věřících shromažd'uje v duchu a v pravdě. Takovým prostorem může být jak tiché místo ve volné př́rodě, tak „bohoslužebná budova“, pro kterou se zavádí označení „sbor CČS“, jež má odkazovat k tradici českobratrských sborů a vyjádřit důraz na liturgický význam k bohoslužbě svolané a shromážděné obce. Řád nepředpisuje konkrétní dispoziční řešení liturgického prostoru, konstatuje pouze, že se skládá z „místa pro duchovního“ a „místa pro ostatní bratry a sestry shromážděné“. Centrem bohoslužebného shromáždění je stůl / oltár, ${ }^{11}$ u kterého slouží duchovní a kolem kterého se shromažd'uje obec po vzoru rodinného setkání v domácnosti. Řád předpokládá existenci pouze jediného stolu / oltáře v liturgickém prostoru sboru. Střed bohoslužebného stolu je určen pro kalich s vínem a paténu s chlebem, které musí být dobře viditelné ze všech míst bohoslužebného prostoru. Ačkoliv řád připouští př́tomnost i jiných liturgických předmětů na stole / oltáři, ${ }^{12}$ žádný z nich nesmí zastínit „obětní kalich“ ve středu stolu či od něho odvádět pozornost. Stůl může být v prostoru sboru doplněn kazatelnou, kterou Kalous charakterizuje jako vyvýšené místo k promluvě / kázání. S ohledem na to, že klade důraz na dobrou slyšitelnost od stolu / oltáře ve všech místech bohoslužebného prostoru, lze předpokládat, že místo pro kázání má být v jeho blízkosti. Součástí liturgického prostoru mají být také umělecká vyobrazení Ježíše, Marie s dítětem nebo významných postav české reformace (Jan Hus, J. A. Komenský) a prapor. Tam, kde je to možné, patří k vybavení sboru i varhany nebo harmonium.

František Kalous shrnul a částečně doplnil svoji charakteristiku znaků liturgického prostoru pro bohoslužebnou praxi Církve československé v krátké studii uveřejněné v časopise Stavitel, periodiku založeném vesměs členy Sdružení architektů, kteří patřili k posledním žákům Jana Kotěry nebo k prvním žákům Josefa Gočára na pražské Akademii výtvarných umění a hlásili se k purismu. ${ }^{13}$ Byl zařazen jako úvod k prezentaci výsledků anonymní ideové architektonické soutěže na „chrámový sbor“ pro potřeby Církve československé, vyhlášené na

11 Oba výrazy jsou používány současně a pojímány jako zaměnitelné.

12 Svíce, živá květina, konvičky na víno a vodu, bohoslužebné knihy (ti. misál, zpěvník a Bible), popř. menší kříž.

13 Srov. Rostislav Švácha. Od moderny k funkcionalismu: promény pražské architektury prvni poloviny dvacátého století. 2., přepracované vydání. Praha: Victoria Publishing 1995, s. 225. 
jaře roku $1924 .{ }^{14}$ Kalous v něm krátce shrnuje přetrvávající různorodost bohoslužebných míst nové církve a zřetelněji, nicméně stále vágními formulacemi vymezuje specifický vztah mezi teologicko-liturgickými zásadami a koncepcí liturgického prostoru, na který by církev při stavbě svých sborů měla brát zřetel. Integrujícím prvkem je princip demokratičnosti, který je z dobového politického a kulturního kontextu přenesen do prakticko-teologické reflexe bohoslužebného shromáždění. S ohledem na tento princip je odlišnost mezi knězem / duchovním a shromážděným lidem pojímána primárně jako funkční, nikoliv jako hierarchická či podstatná. ${ }^{15}$ Při liturgii je tato funkční odlišnost vyjádřena zejména tím, že duchovní je při jejím slavení stále obrácen tváří ke shromážděným, je jejich partnerem v responsivně-dialogických částech a ve své osobě slavící obec sjednocuje. ${ }^{16}$ Demokratičnost shromážděné církve se má projevit v demokratizaci bohoslužebného prostoru. I nadále je $\mathrm{v}$ něm třeba podržet rozlišení mezi presbytářem, místem kněžské liturgické služby u stolu, a lodí, místem shromáždění věřících kolem téhož stolu. Presbytář však nesmí být od lodi oddělen; prostředkem rozlišení se má stát jeho mírné vyvýšení tak, aby duchovní i „obětní stůl“ byli zřetelně viditelní ze všech míst v liturgickém prostoru. ${ }^{17}$ Akcent na dobrou viditelnost stolu / oltáře a duchovního při něm je vyjádřen i pozorností věnovanou osvětlení presbytáře. Pojetí liturgického shromáždění jako setkání rodiny víry v útulném domácím prostředí se promítá také do volby kritérií pro výběr výzdoby prostoru, ke kterým patří vedle umělecké hodnoty díla i míra, s níž přispěje

14 Srov. František Kalous. Sbory Církve československé. Stavitel 5, 8-9 (1924), s. 101-105. Článek téhož názvu i znění s odkazem na původní uveřejnění ve Staviteli otištěn také v týdeníku Český zápas 7, 45, 6. 11. (1924), s. 4. K zadání soutěže viz Ideová soutěž na chrámové sbory církve československé. Ceský zápas 7, 14, 3. 4. (1924), s. 11. Srov. Wenzlová. Sakrálni architektura, s. 168-170.

15 „Kněz, nebo jak v CČS se ř́ká duchovní správce, je bratrem všech přítomných a stejně jako všichni ve shromáždění synem před tváří boží. Nesmí být nijakého povýšení a nepřirozeného oddělení duchovního od věřících." Kalous. Sbory, s. 101. K pojetí svěcení kněžstva a ordinované služby v Církvi československé v zakladatelské generaci viz Karel Farský. Svěcení a zřizování duchovních CČS. In: Zpráva, s. 153-190.

16 „Duchovní CČS je po celou dobu bohoslužby obrácen tvář́ k př́tomným (...) Rozmluva duchovního s př́tomnými - děje se obyčejně zpěvem (...) CČS je plod moderní demokracie, ve které každý má se uplatniti. Proto písně v CČS při bohoslužbě i odpovědi duchovnímu zpívají všichni a tak styk obou činitelů - lidu i duchovního - je intimnější, přátelštější a oduševnělejší (...) duchovní, který sjednocuje ve své osobě všecky shromážděné bratry a sestry.“ Kalous. Sbory, s. 101-102.

17 „Proto kněžiště (presbyterium) bývalých římských chrámů nemá býti plně odděleno od lodi, místa, kde se shromaždují věřící. Jen aby všichni viděli toho, kdo bohoslužbu vede, stojí duchovní na vyvýšeném místě.“ Kalous. Sbory, s. 101. 
k dotvoření intimní rodinné atmosféry bohoslužebného prostoru. Jas, radost, svit, vnitřní produševnělost a přátelskou pospolitost pokládá František Kalous za základní hodnoty, které mají utvářet jednotu mezi shromážděnou obcí a jejím bohoslužebným místem tak, aby společně vyjadřovaly radostnou evangelijní zvěst v současném světě. ${ }^{18}$

Shrňme nyní základní prvky liturgického prostoru sboru Církve československé v pojetí Františka Kalouse, které tvořily východisko teologicko-architektonických úvah Miroslava Kouřila. Bohoslužebný prostor má charakter místa pro rodinná setkání, je celý prosvětlený a převažují v něm jasné a radostné barvy. Jedná se o prostor jednotný, s funkčním rozlišením presbytáře a lodi, které však nesmí vést k jejich oddělení. Jeho základním objektem je bohoslužebný stůl, který spolu s liturgickou službou kněze tvoří střed, jenž sjednocuje shromážděnou obec i její bohoslužebné místo. S ohledem na tento střed je třeba pojímat akustickou a optickou jednotu prostoru tak, aby byla zajištěna dobrá slyšitelnost a viditelnost $\mathrm{v}$ rámci celého prostoru. Tomu mohou napomoci bodové osvětlení stolu i duchovního a funkčně vyvýšená místa pro stůl a kazatelnu.

\section{Standardizace sborů a liturgického prostoru (1928-1932)}

Pro první léta po založení Církve československé byla typická různorodost bohoslužebných míst, na kterých se členové nové církve shromažd'ovali ke společnému slavení liturgie, jejíž konkrétní podoba byla často odvislá „od místa a individuality duchovního“. ${ }^{19}$ Zatímco k typizaci liturgického života v Církvi československé postupně docházelo přijetím a poměrně rychlým rozšířením Liturgie připravené péčí Karla Farského a masově distribuované do náboženských obcí církve zejména jako součást opakovaně velkým nákladem vydávaného Zpěvníku písní duchovních CČS, v oblasti výstavby sborů a adaptací staveb

18 „Kristus přinesl světu evangelion - dobrou, radostnou novinu, aby touto člověk povznesl se ve svém životě pozemském k výšinám nebeským. Proto jas, radost, svit, vnitřní produševnělost, přitom přátelská pospolitost mají sjednotiti, posvětiti všechen sbor, shromáždění věřících ve sboru, chrámu československém. "Kalous. Sbory, s. 102.

19 „Když založena byla církev československá, zdálo se, že postačí jí dosavadní kostely rímsko-katolické, v kterých konaly se první bohoslužby československé. Vedle toho některé obce CČS nalezly útulku v kostelech českobratrských. Jinde slavily se bohoslužby také $\mathrm{v}$ sálech radnic i hostinců a také v místnostech školních. V nich utvářela se bohoslužba CČS. Z počátku byla slova bohoslužby pouhým překladem z obřadní knihy (misálu) církve římské. Dle místa a individuality duchovního utvářel se pak vlastní ritus CČS.“ Kalous. Sbory, s. 101. 
k bohoslužebným účelům k podobné standardizaci z počátku nedocházelo. Situaci se na přelomu 20. a 30. let minulého století pokusila řešit Ústřední rada Církve československé.

\subsection{Smèrnice pro stavbu sborů a far Církve československé}

Prvním krokem ke standardizaci sborových staveb bylo schválení a zveřejnění pro církev závazných Směrnic pro stavbu sborů a far Církve československé, které vypracoval stavitel a architekt Ladislav Čapek. ${ }^{20}$ Smèrnice preferují situování sborové stavby ve volném prostoru města či obce, nejlépe s přilehlým parkem. Za normu je pokládána stavba, která spojuje „sbor“ a „faru“. Sborová stavba má být složena ze „sboru pro bohoslužby“a „přednáškové síně“. Ke sboru přilehlá fara má zahrnovat kancelář duchovní správy, archiv, zasedací síň, dále byty faráře a pomocného duchovního správce, popř. další hospodářské objekty. Směrnice věnuje pozornost i sborovému liturgickému prostoru, pro který se užívá výraz „síň“. Jeho významovým středem je „prostor pro obětní stůl“, který má být oproti „prostorům pro obecenstvo“, jak dokument označuje místo pro shromážděný lid, „mírně zvýšený“. Stůl / oltář je doplněn zprava situovaným „řečništěm“ (kazatelna). Je třeba dbát o stejnoměrné osvětlení celého liturgického prostoru denním světlem i umělým osvětlením, s důrazem na řádné osvětlení stolu / oltáře. Výzdoba liturgického prostoru má být „prostá, klidná, důstojná a omezena na míru nejmenší“. Směrnice pak preferují kříz se sochou Krista, obraz či bustu Jana Husa, prapor či biblické nápisy na stěnách (popř. emblém CČS) před obrazy a sochami. Důraz je kladen na uměleckou hodnotu kteréhokoliv díla, jež se stane součástí sborového liturgického prostoru.

\subsection{Typizace sborové stavby}

Přetrvávající neutěšená situace $\mathrm{v}$ kvalitě předkládaných projektů na stavbu sborů pro Církev československou vedla Stavební radu při Ústřední radě CČS k předložení návrhu tří typizovaných sborových staveb. ${ }^{21}$ Návrhy typizovaných sborů řeší zejména problematiku sborových staveb, nikoliv farní budovy. V komentáři uveřejněném v Českém zápase spolu s představením jednotlivých typizovaných sborových staveb

20 Srov. Ladislav Čapek. Směrnice pro stavbu sborů a far církve československé. Český zápas 11, 37, 12. 9. (1928), s. 2-3.

21 Srov. Anonym. Stavba našich sborů. Český zápas 15, 5, 3. 2. (1932), s. 35-36; (pokračování) Anonym. Stavba našich sborů II. Český zápas 15, 6, 10. 2. (1932), s. 42-43; (závěr, bez názvu) Český zápas 15, 7, 17. 2. (1932), s. 50-51. 
je kladen důraz na to, že stavebně-architektonické řešení sboru musí primárně vyhovovat bohoslužebným a estetickým požadavkům. Jiné zamýšlené způsoby užívání sborových prostor musí být těmto požadavkům podřízeny a nemají být řešeny na úkor primárního účelu stavby, tj. slavení bohoslužby. Dokument se tak nejspíše vyrovnává s praxí, ve které se při plánování stavby sboru toto hledisko neuplatňovalo a jejich multifunkční charakter postrádal zřetelnou hierarchii účelů s ohledem na poslání ( missio) církve. Náležitá pozornost má být věnována zvláště prostoru pro obětní stůl, pro nějž se užívá označení „obětiště“. ${ }^{22}$ Obětní stůl může být zhotoven ze dřeva nebo kamene a musí být volně přístupný ze všech stran. Obětiště (presbytář) má být natolik prostorné, aby v něm mohlo při slavnostních př́ležitostech sloužit více duchovních u stolu a do sebe pojalo kříz nebo sochu Krista. Všechny tři zveřejněné typy sborové stavby mají podélné obdélníkové půdorysné řešení s presbytářem ve formě připojené a mírně vyvýšené (cca $50 \mathrm{~cm}$ ) niky. Jiná dispozice liturgického prostoru není navržena ani diskutována. Komentář se rovněž zmiňuje o „řečništi pro promluvy“, které je třeba ve sboru zřídit, nebot' kázání se již nadále nemá dít od obětního stolu. Kazatelna může být přenosná, např. ve tvaru velmi jednoduchého stolku. V otázce míst k sezení v lodi sboru jsou upřednostněny lavice před dosud běžně užívanými židlemi, ,ježto činí klidnější dojem“. Klid, důstojnost a umělecká hodnota jsou rovněž základní kritéria pro výzdobu sborového liturgického prostoru.

Proces standardizace a typizace sborových staveb s sebou přinesl dotvoření teologicko-architektonických zásad, načrtnutých v prvních letech po vzniku církve. Nicméně neposkytl hlubší teologické promyšlení tématu, které nadále $\mathrm{v}$ nové církvi citelně absentovalo. Většina textů svědčí o záměrné volbě sekulárních, nenáboženských termínů pro charakteristiku sborových staveb. Př́kladem je volba výrazu „síň“ pro liturgický prostor, „řečniště“ pro kazatelnu a „promluva“ pro homilii / kázání. Jsou příznakem obecnější tendence pojímat liturgický prostor civilně, z funkčního hlediska. Jediným explicitně teologickým objektem v prostoru je obětní stůl s kř́ižem (nebo sochou) Krista. Typizovaná dispozice sborového liturgického prostoru a statické vymezení

\footnotetext{
22 Stručně o významu obětního jazyka v kontextu liturgie pojednává katechismus Učení náboženství krestáanského, schválený na 2. zasedání I. sněmu Církve československé v Praze roku 1931. V zásadě se vztahuje pouze k historické oběti Ježíše Krista na kříži, která je při slavení liturgie zpřítomněna, a k aktu obětování sebe a svých schopností Bohu v jednotě s Ježíšem Kristem.
} 
všech jeho složek (lavice, stůl, vzájemná pozice shromážděného lidu a duchovního, místo pro varhany a pěvecký sbor, osvětlení) vyjadřovaly a posilovaly neméně typizovanou a víceméně statickou formu liturgického slavení podle Liturgie Karla Farského. Dramaticko-liturgická iniciativa v ní vycházela vždy od duchovního z prostoru obětního stolu směrem k lidu shromážděnému v lodi a jejím téměř výhradním komunikačním prostředkem byly oční kontakt, mluvené nebo zpívané slovo a gesta, jejichž četnost v kontextu liturgie byla minimalizována. ${ }^{23}$ Liturgie sama tak kladla požadavky spíše praktického rázu (viditelnost, slyšitelnost, př́ístupnost, osvětlení), její teologické akcenty se v prostoru soustředily na obětní stůl a zásadu demokratičnosti, promítnutou do vztahu mezi knězem a shromážděným lidem (vztah presbytáře a lodi) a mezi jednotlivými členy shromážděné obce (v lodi nejsou privilegovaná místa).

\section{Pojetí sborové stavby a jejího liturgického prostoru v myšlení Miroslava Kouřila}

Miroslav Kouřil ${ }^{24}$ vstoupil do probíhající diskuze o sborové výstavbě v době, která byla v Církvi československé poznamenána napětím mezi vedením církve, v čele s patriarchou Gustavem Adolfem Procházkou, a k situaci církve i stylu jejího vedení velmi kritickou skupinou duchovních i laiků, vedenou především Františkem Kovářem a Antonínem Hartlem, kteř́ založili v rámci církve Společnost Dr. Karla Farského (1933-1938). ${ }^{25} \mathrm{~V}$ ní začal po dokončení svých studií architektury na ČVUT v Praze intenzivně působit i M. Kouřil, který se zaměřil na aktuální problematiku církevního umění a architektury. Působil jako redaktor a grafik časopisů Rozsévač a Nový zápas a byl spoluzakladatelem velmi činné Sekce výtvarných umělců a architektů při Akci církevní spolupráce v Církvi československé. Příznačným pro jeho přístup

23 Ačkoliv bylo v Církvi československé velmi záhy po jejím vzniku obnoveno přijímání eucharistie sub utraque, trvalo velmi dlouho, než byla také obnovena praxe jejího častého přijímání. Běžnou praxí až do osmdesátých let minulého století bylo přijímání 1x měsíčně či déle.

${ }^{24}$ K základním biografickým údajům, které však zcela opomíjejí jeho činnost v Církvi československé, srov. Josef Tomeš a kol. Český biografický slovnik XX. století. II. díl K-P. Praha a Litomyšl: Paseka 1999, s. 144.

25 K celkovému historickému kontextu srov. Jaroslav Hrdlička. Život a dílo prof. Františka Kováre: pŕibèh patriarchy a učence. 1. vyd. Brno: L. Marek 2007, s. 165 a dále. Srov. Wenzlová. Sakrálni architektura, s. 176-180. Autorka rovněž upozorňuje, že některé své příspěvky uveřejňoval Miroslav Kouřil pod redakční značkou „ilem“. 
k problematice sborových staveb a plánování jejich další výstavby se stalo důsledné uplatnění funkcionálního hlediska a moderních metod organizace výstavby, jak se uplatňovaly v rámci soudobých modernistických architektonických směrů (purismus, funkcionalismus) při urbanistickém plánování či projektech sociálně dostupného moderního bydlení. ${ }^{26}$

\subsection{Církevní dům - multifunkční církevní stavba}

Poslání církve v moderní vědecko-průmyslové společnosti pokládal M. Kouřil za základní východisko i kritérium pro koncipování komplexní ideje sborové stavby a jejího liturgického prostoru. Vymezil je především funkčně prostřednictvím úkolů církve ve vztahu ke společnosti, které rozdělil do čtyř skupin. Základní, pro identitu církve podstatnou skupinu tvoří úkoly duchovní, z nichž hlásání Božího slova je úkolem primárním. Druhou skupinu formují úkoly výchovné. Ty jsou plněny jednak činností osvětově-kulturní, zaměřenou zejména na dospělé členy církve i na širší veřejnost, jednak působením pedagogicko-výchovným, cíleným na školní děti a mládež. K dalším úkolům církve patři veřejná administrativa, která je církvi uložena státem (např. matriční právo), a vnitrocírkevní administrativa spojená se správou náboženských obcí. Poslední skupinu tvoří úkoly sociální. V obecné rovině jejich zajištění a plnění náleží podle M. Kouřila modernímu státu, nicméně církev může se souhlasem státu převzít sociální péči o vybrané skupiny svých členů (osiřelé děti, děti zaměstnaných matek, senioři a sociálně slabí či znevýhodnění). ${ }^{27}$

Své úkoly církev realizuje primárně prostřednictvím náboženských obcí, ve kterých jsou sdruženi členové a členky církve na základě územního principu. Centrem života náboženských obcí se v pojetí Miroslava Kouřila má stát „církevní dům“, s ohledem na pluralitu úkolů církve jim odpovídající a hierarchicky uspořádaná multifunkční stavba. Idea církevního domu patří k nové fázi vývoje Církve československé, která prošla obdobím zakladatelským a vstupuje do období budovatelského. Samotnou problematiku církevního domu pojímal rovnocenně jako

26 Srov. Švácha. Od moderny k funkcionalismu, s. 263-323; Tim Benton. Building Utopia. In: Christopher Wilk (ed.). Modernism: designing a new world 1914-1939. 1. vydání. London: V \& A Publication 2006, s. 150-247.

27 Srov. Miroslav Kouřil. Stavba sboru - problém funkce a prostoru. Náboženská revue 10 (1938), s. 183-186. Srov. starší studii Miroslava Kouřila Církevní dům. Nový zápas 1, 4 (1935), s. 57-61 a týž. Církevní dům (dokončení). Nový zápas 1, 5-6 (1935), s. 90-93. Týž. Sít staveb církve čsl. Náboženská revue 10 (1938), s. 314-318. 
otázku jeho funkčnosti, výtvarné hodnoty a organizace a plánování výstavby. ${ }^{28}$

Z hlediska funkčnosti navrhl M. Kouřil rozčlenit prostory církevního domu do tří skupin, které odpovídají různým úkolům církve. Duchovní úkoly mají být primárně realizovány ve „sborové místnosti“, pro kterou později zavede označení „liturgická síň“. Byty pro duchovní a ubytovací kapacity pro osiřelé děti, zestárlé a sociálně potřebné členy církve tvoří ve svém celku prostory obytné funkce. Části církevního domu vyhrazené pro kulturní, vzdělávací, výchovnou a technicko-administrativní činnost tvoří prostory administrativně výchovné funkce. Vzájemné vztahy mezi skupinami prostorů osvětlil M. Kouřil pomocí provozních diagramů, které patřily k jeho základním pracovním nástrojům. ${ }^{29}$

Zřetel organizačně-plánovací se projevil nejvýrazněji v Kouřilově důrazu na nezbytnost koncipovat výstavbu církevního domu etapově, přičemž jednotlivé etapy mají odpovídat míře organizovanosti místní náboženské obce a jejího začlenění do celkové sítě církevních staveb na určitém území. ${ }^{30}$ Nejelementárnějším liturgickým stavebním útvarem je jednoduchá „zvonička nebo jiný tvar malé památkové stavby“ s dostatečně volným prostranstvím ke shromáždění místní křest'anské obce pod širým nebem. Centrem takového živého útvaru k bohoslužbě shromážděné církve je přenosný liturgický stůl, instalovaný pouze po dobu konání liturgie. Výrazným způsobem se zde uplatňuje zásada ekleziality liturgického slavení a princip: jedno společenství, jeden stůl / oltár. ${ }^{31}$ Druhou fází výstavby je realizace stavby „sboru“, jehož dispozice obsahuje „liturgickou síň a předsín““. Liturgickou síní míní M. Kouřil stálý, stavebně vymezený prostor určený k bohoslužebnému slavení. Předsíň pak označuje širší zázemí sboru, určené zejména pro různorodé administrativní úkoly náboženské obce (duchovní správa a schůze rady starších, mládeže, sborů sociální práce, sborů služby apod.). Druhá etapa výstavby představuje přechod od sboru k budování církevního domu. Spočívá ve stavební realizaci nových prostor, které umožní jednak prostorovou diferenciaci administrativních úkolů (tj.

28 „Přesto je však chybou, pro postavené sbory již neodčinitelnou, že hlavní pozornost ve stavební otázce církve věnována problémům finančním, a nikoli problému teorie utváreni církevního domu (= sboru) jako svébytného útvaru, který vyrůstaje z odlišného organizačního utvárení církve, má svou zvláštni životni zákonitost i své speciální požadavky výtvarné." Kouřil. Církevní dům, s. 57.

30 Srov. týž. Sít staveb, s. 315.

31 Srov. tamtéž, s. 314. 
samostatné kanceláře pro duchovní správu, radu starších a jednotlivé sbory / odbory), jednak rozvoj kulturních a výchovně-vzdělávacích činností (kulturní sál, společenská místnost, místnost pro mládež). Samostatnou etapou je př́stavba bytů pro duchovní a správce objektu. Etapou poslední pak je vybudování kapacit, integrujících funkci dětského domova, domova seniorů a sociálního bydlení. ${ }^{32}$

Pokud bychom užili současnou terminologii, i.e., církevního domu odpovídá konceptu církevního komunitního centra. Reagovala na dobová, a jak se později ukázalo, příliš optimistická očekávání kontinuálního růstu počtu členů nové církve a jejich aktivního zapojení do místního společenského a kulturního života prostřednictvím organizovaných náboženských obcí. Z pohledu liturgické teologie v něm zůstává přesvědčivá a trvale platná zásada, že slavení liturgie je fundamentálním a specifickým znakem církve, kterým se liší od ostatních forem pospolitosti. Liturgický prostor, resp. liturgická síň je proto jistou „arché“, teologickým i stavebně-architektonickým principem církevního domu a počátkem místního společenství církve. ${ }^{33}$

\subsection{Liturgická sín}

Principiálním prostorem místního křestanského společenství je prostor určený pro slavení liturgie, který Miroslav Kouřil nejprve označuje výrazem „sborová místnost“ ${ }^{34}$ později pro něj zavádí označení „liturgická síň “. ${ }^{55} \mathrm{Z}$ pohledu M. Kouřila má být liturgická síň středem každé autentické církevní stavby, nebot' liturgii pokládá za základní činnost církve, ze které se odvozují a ke které jsou vztaženy všechny její ostatní činnosti. ${ }^{36}$ Jedná se o natolik charakteristický rys, že je to právě liturgická síň, tedy prostor slavení liturgie, jež církevní stavbu odlišuje od staveb jiných, jejichž rozdílné funkce (obytné, kulturní, sociální apod.) se mohou s některými funkcemi církevního domu shodovat. Základní otázky, které je třeba v souvislosti s liturgickým prostorem církevního domu klást, jsou základní tvar prostoru, poloha, intenzita, směr a barva

\footnotetext{
Srov. týž. Církevní dům, s. 58-60; srov. týž. Stavba sboru, s. 186.

„Vyjděme z přesvědčení, že církevní stavba pro jakýkoliv územní obvod má sloužit především liturgii. Všechny ostatní funkce jsou tomuto úkolu přidány a rozvíjejí ho jednak místně..., jednak stupněm organizačním, jemuž slouží.“ Kouřil. Sít' staveb, s. 315.

34 Srov. týž. Církevní dům, s. 92.

35 Srov. týž. Stavba sboru, s. 186.

36 Srov. Miroslav Kouřil. Chceme se odlišit! Náboženská revue 11 (1939), s. 51-56, (dokončení) 116-120.
} 
světla, a konečně členění a výzdoba stěn spolu s dalšími prvky výtvarné funkce. ${ }^{37}$ Nejvýznamnější z nich je vztah mezi prostorem a světlem. ${ }^{38}$

Není to však prostor, co určuje liturgii. Naopak, liturgické slavení určuje podobu liturgického prostoru. Proto je charakter liturgické síně odvislý od charakteru liturgie, která vymezuje a určuje její dispozici a výtvarné pojetí. Otázku vztahu mezi liturgií a jejím prostorem pojímal M. Kouřil konkrétně jako určení „znaku, daného odlišností kultu““ ${ }^{39}$ Pouze ve specifickém, tedy od jiných církví odlišném charakteru liturgické praxe lze spatřovat oprávněnost otázky po zásadách, jimiž se má řídit tvorba liturgického prostoru v Církvi československé. Specifický znak liturgické síně tak má být určen základním charakterem Liturgie patriarchy Karla Farského. Za její podstatný znak pokládal M. Kouřil „kolektivitu“40, jíž míní skutečnost, že liturgie je aktem celé shromážděné křest’anské obce. Spolu s dosavadní naukou nové církve viděl ve službě duchovního / kněze funkční, nikoli podstatnou odlišnost od služby obce v kontextu slavení liturgie. ${ }^{41}$

Z principu kolektivity liturgie $\mathbf{v}$ Církvi československé vyvodil M. Kouřil základní znak jejího liturgického prostoru, shodný s reformační tradicí sborových staveb. Liturgická síň má být jednotným a neděleným prostorem. ${ }^{42}$ To nejprve znamená, že se jedná o prostor, ve kterém není přítomná jakákoliv hierarchie dílčích míst, tedy ani presbytáře jako kněžského prostoru ve vztahu k lodi jako místu shromáždění laiků, ani zvláštních míst vydělených v lodi pro významné členy obce. ${ }^{43}$ Liturgická síň má být důsledně teocentrickým, a proto demo-

37 Srov. Kouřil. Stavba sboru, s. 246.

38 Tento vztah patřil k základním tématům architektonické moderny.

39 Srov. Kouřil. Chceme se odlišit, s. 51-52.

40 Srov. týž. Církevní dům, s. 92n, kde se tento termín objevuje. Ačkoliv jej neužívá souvisle, pokládám jej za vhodný zastřešující výraz. M. Kouřil jej mimo jiné užívá také $\mathrm{k}$ charakteristice obecenstva $\mathrm{v}$ kontextu divadla.

41 „Odlišné pojetí bohoslužby $\mathrm{v}$ českomoravské církvi nese především požadavek, aby duchovní byl pouze jedním z jejích účastníků a nebyl povyšován na prostředníka Božího. Duchovní liturgii vede, mezi ním a shromážděním rozvíjí se v jejím průběhu zpívaný dialog, avšak z celé textace je patrné, že i tehdy, mluví-li duchovní sám, mluví jen jako jeden z př́tomných, vyvolený shromáždění, který má přednést modlitbu procitovanou všemi. (...) Nejplněji má se toto obecenství projevit v modlitbách kolektivních (na př. společný zpěv Otčenáše) a v hromadném, jednohlasém zpěvu písnè.“ Miroslav Kouřil. Umění v církvi čm. Český zápas 26 (1943) č. 5, s. 34-36; č. 7, s. 46-47; č. 9 , s. $54-55$; č. 11, s. 62 ; č. 12 , s. $66-67$; č. 14 , s. $74-75$; č. 16, s. $82-83$; č. 18 , s. $90-91$; zde s. 66. Tato série článků byla M. Koư̌ilem původně zamýšlena a připravena jako samostatná publikace věnovaná teoretickým a praktickým otázkám stavby sboru.

42 Srov. Kouřil. Stavba sboru, s. 246.

43 Srov. týž. Církevní dům, 90-93; srov. týž. Stavba sboru, s. 248. 
kratickým prostorem, který ztělesňuje povahu církve jako společenství „dětí Božích“. Jednota a nedělenost prostoru však neznamenají jeho homogennost. Jednota prostoru je tvořena „dvěma splývajícími protipóly“ v dynamickém napětí, které reflektují dialogické napětí i jednotu společenství, jež slaví bohoslužbu na základě Liturgie patriarchy Karla Farského. V liturgii jsou těmito splývajícími protipóly duchovní s jejich kněžskou službou a slavící shromážděná obec. V liturgické síni pak syntetický celek tvoří liturgický stůl s kazatelnou a „shromaždiště““ členů obce. ${ }^{44}$ Je však třeba vyloučit jakýkoliv architektonický prvek, jenž by zaváděl do takto jednotného, vnitřně rozlišeného liturgického prostoru oddělení kněžiště od místa vyhrazeného pro shromážděnou obec. Takovým prvkem může být široké monumentální schodiště či koncipování presbytáře jako i pouze mělké niky či apsidy. S presbytářem ve formě niky obdélníkového tvaru jsme se setkali ve všech návrzích typizovaných sborových staveb, uveřejněných počátkem 30 . let v církevním tisku. Ve svých návrzích sborových staveb však Miroslav Kouřil tuto formu nikdy neuplatnil a důsledně trval na nutnosti řešit otázku presbytáře a místa liturgického stolu důsledně v rámci konceptu jednotného a neděleného prostoru.

Jednota a nedělenost jsou základními teologicko-architektonickými principy moderního liturgického prostoru. Jejich konkrétní zhmotnění však musí být podle M. Kouřila ponecháno tvůrčím schopnostem a dovednostem architektů a výtvarníků. Má se stát také předmětem laboratorního experimentování. ${ }^{45}$

\subsubsection{Liturgický kout}

Prostor liturgické síně je nejen jednotný a nedělený, je také prostorem s jedním centrem, a proto dle M. Kouřila zásadně centrálním, který koncentruje pozornost shromážděné obce k jednomu místu. ${ }^{46} \mathrm{Za}$ takové

44 „Dispozičně je vytvářena dvěma splývajícími protipóly: liturgickým stolem s řečništěm (= kazatelnou) a shromaždištěm členů obce. Ideově plyne z liturgie, že je to synthetický celek, v němž jsou obě složky rovnocenné! Tomu nasvědčuje kolektivnost modliteb v liturgii i možnost, v níž mluví kněz.

Funkčně z toho plyne: Oba póly liturgické síně mají být v jednom prostoru, ne odděleny po vzoru katolickém (kněz v apsidě, věřící v chrámové lodi a postranních lodích).“ Kouřil. Stavba sboru, s. 185.

45 Srov. Kouřil. Stavba sboru, s. 245, 247-248; srov. Miroslav Kouřil. Liturgická síň. Český zápas 25, 22 (1942), s. 170-171.

46 „Forma liturgické síně v dispozici musí být jednoduchý nebo kř̀ivkově složitý obrazec, vždy však centrálního, uzavřeného charakteru (...) jednolitý, soustředěný (...) Zabírá jednotlivce do sebe i ostatního shromáždění.“ Kouřil. Stavba sboru, s. 248. 
místo pokládal prostor liturgického stolu, pro který zavedl nejprve velmi prozaické označení „liturgický kout“ ${ }^{47}$ později „prostor večeře Páně“ ${ }^{48}$ který již jednoznačně vystihl jeho liturgický charakter a význam. Pojmem liturgického koutu zaměřil $M$. Kouřil pozornost jednak na vztah liturgického stolu k celku bohoslužebného prostoru, jednak na uspořádání a výtvarné pojetí blízkého okolí stolu. ${ }^{49}$ Právě odlišné pojetí funkce a výtvarného zpracování liturgického koutu stanovil za základní diferenciační znak liturgického prostoru jednotlivých křestanských tradic.

Specifický charakter liturgického koutu vymezil M. Kouřil nejprve jeho důsledným začleněním do jednoty liturgického prostoru sboru, v jehož rámci je odlišen funkčně pouze mírným vyvýšením nad své okolí, jež má vyjádřit jeho centrálnost a zajistit jeho dobrou viditelnost. ${ }^{50}$

Za další specifický znak označil prvky liturgického mobiliáře, které tvoří stálé vybavení liturgického koutu. Nejvýznamnějším z nich je liturgický stůl. Ten je z jedné strany doplněn vhodným stolkem či pultem pro zvěstování slova Božího, z druhé strany pak křtitelnicí. Na její trvalou a viditelnou prítomnost $\mathrm{v}$ liturgickém prostoru sboru kladl M. Kouřil značný důraz. ${ }^{51}$ Velmi moderní požadavek, aby do křtitelnice stále proudila voda, se stane součástí návrhu nových Směrnic pro budování sborových staveb, na jejichž přípravě a formulaci se M. Kouřil významně podílel. ${ }^{52}$ Pult pro zvěstování Božího slova má být umístěn ve stejné rovině s liturgickým stolem. Jeho umístění ve formě tradiční kazatelny ve výšce nad celým shromážděním posoudil M. Kouřil nikoli jako znamení autority Božího slova, ale jako výraz klerikální hierarchické moci. ${ }^{53}$ Promýšlení moderního architektonického a výtvarného uchopení zvěstování v rámci liturgie pokládal za prvořadý úkol. ${ }^{54}$

Bezprostřední okolí liturgického stolu má být v nejjednodušším případě tvořeno pouze stěnou umístěnou za ním. Pokud bude zpracováno výtvarně jiným způsobem, pak je třeba brát zřetel na zásadu, že stůl nesmí mít výtvarného soupeře, který by tříštil pozornost. Jednou

\footnotetext{
7 Srov. Kouřil. Chceme se odlišit, s. 53; srov. týž. Liturgická síň.

Srov. týž. Umění v církvi, s. 66.

49 „Je-li skutečně středem shromáždění liturgický stůl jako střed pozornosti a bod, v němž je opřena kolektivní víra shromáždění, pak tento střed nesmí mít výtvarného soupeře, který by pozornost odváděl jinam.“ Miroslav Kouřil. Kapitoly o umění. Nový zápas 1, 9+10 (1935), s. 132-135 a 147-150, zde s. 134.

50 Srov. týž. Církevní dům, s. 90-93.

51 Srov. týž. Umèní v církvi, s. 66.

52 Srov. Miroslav Kouřil. K diskusi o Směrnicích. Český zápas 25, 39 (1942), s. 306-308.

53 Srov. týž. Stavba sboru, s. 249.

54 Srov. Miroslav Kouřil. Střepiny. Český zápas 25, 12 (1942), s. 91.
} 
z možností výtvarného zpracování liturgického koutu je umístění realistické sochy či plastiky Ježíše Krista. Motiv výzdoby má pak být vždy takový, aby přispíval k posílení jednoty a celistvosti liturgického prostoru a zahrnul shromážděnou obec do ohniska liturgického stolu..$^{55}$

\subsubsection{Liturgický stůl}

Dosavadní postup výkladu pojetí liturgického prostoru v myšlení M. Kouřila zaměřoval pozornost stále více $\mathrm{k}$ tématu liturgického stolu. Oproti převažujícímu jazyku oficiálních dokumentů, ve kterých se užívala označení „oltář““, „obětní stůl“ a „obětiště“, užíval M. Koư̌il důsledně výraz „liturgický stůl“, popř. jen „stůl“. Význam označení „oltář“ zúžil na téma hrobu, které považoval pro kontext slavení eucharistie za neadekvátní. ${ }^{56} \mathrm{~S}$ odkazem na význam zpřítomnění poslední večeře Ježíšovy s učedníky v Liturgii patriarchy Karla Farského pokládal označení „stůl“ za jediné smysluplné.

M. Kouřil opakovaně zdůrazňoval, že liturgický stůl je významovým a architektonickým středem liturgického slavení, resp. prostoru. Má být umístěn ve volném prostoru, v určitém odstupu od shromážděné obce a zároveň mezi jejími členy tak, aby bylo patrné, že je obec shromážděna kolem něj a všichni k němu mají rovnocenný přístup. Trvalá přítomnost duchovního při stolu v prủběhu bohoslužebného slavení je dána pouze jeho specifickou liturgickou funkcí, nikoliv svého druhu podstatnou odlišností od shromážděného společenství pokřtěných. ${ }^{57}$ Pro myšlení M. Kouřila typický zřetel k funkci se projevil i v samotném pohledu na liturgický stůl, který příležitostně označil za „kus nábytku, jímž je zařízena světnice, kde se shromažd'uje rodina dítek Božích“. ${ }^{58}$ Konkrétní zpracování tvaru liturgického stolu a jeho případná výzdoba nesmí zastřít jeho charakter i funkci stolu, kterou spatřoval mimo jiné $\mathrm{v}$ tom, že slouží k prostému odkládání kalichu s vínem a patény s chlebem. ${ }^{59}$

55 „Okolí liturgického stolu bude $\mathbf{v}$ nejjednodušším případě jen stěna za stolem (...) v žádném případě kout nebo relief výzdoby nestal zástupcem apsidy. Motiv výzdoby měl by být rozlétlý do stran, aby svými rameny objal a vyplnil celý prostor a zahrnul všechno shromáždění do ohniska liturgického stolu; k němu při liturgii je soustředěna optická pozornost shromáždění.“ Kouřil. Chceme se odlišit, s. 53-54; srov. též Kouřil. Kapitoly o umění, s. 134.

56 Srov. týž. Stavba sboru, s. 249; srov. týž. Liturgická síň, s. 170.

57 Srov. týž. Stavba sboru, s. 185 a jinde.

58 Srov. týž. Chceme se odlišit, s. 53.

59 Srov. týž. Stavba sboru, s. 249. 
M. Kouřil se vlastně brání tomu, aby byla samotnému liturgickému stolu přiznána nějaká symbolická hodnota.

Pokud funkční vysvětlení liturgického stolu objasňuje jeho liturgický význam, jak máme rozumět tomu, že M. Kouřil zároveň trvá na jeho centrálním významu pro slavení liturgie i uspořádání celého liturgického prostoru? Centrálnost liturgického stolu spočívá překvapivě v tom, k čemu funkčně odkazuje. A tím jsou kalich s vínem, paténa s chlebem a symbolické jednání s nimi. Pokud není slavena eucharistie, má střed liturgického stolu zůstávat prázdný, aby tato „nepřítomnost“ trvale odkazovala k dění, jemuž stůl při slavení bohoslužby slouží. ${ }^{60}$ Centrálnost stolu tak spočívá v symbolickém jednání, jemuž slouží, ke kterému odkazuje a jehož charakter, tj. stolování s Pánem, významně spoluutvář́.

K jasnějšímu porozumění povaze centrálního symbolického jednání je nicméně zapotřebí odstoupit od samotného liturgického stolu a zhlédnout z nového úhlu pohledu celek liturgického prostoru. Kolektivitu bohoslužebného slavení podle Liturgie patriarchy Karla Farského více než vizuální sjednocení prostoru postihuje a posiluje jeho jednota akustická, ${ }^{61}$ nebot' liturgii $\mathrm{M}$. Kouřil pokládá primárně za dílo slovesně-hudební, a nikoli za rituálně-symbolické jednání, k němuž patři „děj“ či dynamický pohyb v prostoru. ${ }^{62}$ Proto je v zásadě jediným důvodem pro vyčlenění prostoru liturgického stolu mírným vyvýšením viditelnost gest kněze a jeho symbolického jednání s kalichem vína a chlebem. ${ }^{63}$ Analogie mezi liturgickou a koncertní síní (!) je více než

${ }^{60}$ „Střed stolu by měl být vždy volný; do něho postaví duchovní kalich a patenu, které používá při liturgii (...) nic, co by zakrývalo nebo tvarově konkurovalo s kalichem, užívaným při liturgii (...) střed prázdný (...) připraven k něčemu, čemu slouží; nebot' liturgický stůl není výzdoba, ale kus nábytku, jímž je zařízena světnice, kde se shromažd'uje rodina dítek Božích (...) hromadění symbolů na jednom místě by bylo nevhodné.“ Kouřil. Chceme se odlišit, s. 53-54.

${ }^{61}$ „Nejplněji má se toto obecenství projevit v modlitbách kolektivních (na př. společný zpěv Otčenáše) a v hromadném, jednohlasém zpěvu písně. V těchto okamžicích má prostor liturgické síně souznít se shromážděním jako hudební nástroj. Toto vymezení vyžaduje akustické řešení liturgické síně na principu resonance, tedy zařízení prostorů, které by měly obdobnou funkci, jakou má např. u houslí resonanční sín. Shromáždění je pak strunovým zařízením, na němž tvůrčí ruka náboženské zkušenosti hraje liturgickou partituru chvály českomoravského vyznání o velikosti království Božího na zemi.“ Kouřil. Umění v církvi, s. 66.

${ }^{62}$ S odkazem na koncept „musické stavby“ Arne Hoška uvádí M. Kouřil, že „pojmu stavby musické bude nejplněji odpovídat církevní stavba, tedy i sbor naší církve. Nebot' kde jinde než u ní požadavek souznění prostoru s provozovaným dílem slovesně-hudebním (liturgie) bude postaven úplněji.“ Kouřil. Umění v církvi, s. 66. 
zřetelná na dvou Kouřilových soutěžních návrzích, které připravil ve spolupráci s Arne Hoškem. První se týká nové sborové stavby Církve československé pro Prahu-Záběhlice, druhý Janáčkovy síně, koncertního sálu pro Prahu. ${ }^{64}$

\section{Závěr}

Miroslav Kouřil se pokusil v druhé polovině 30. let minulého století aktualizovat základní zásady pro výstavbu sborů, které do života Církve československé v prvních letech vnesl František Kalous. V jistém smyslu tak učinil $v$ reakci na tendenci ke standardizaci a typizaci sborových staveb, k nimž přikročila oficiální místa církve počátkem 30 . let pod tlakem neutěšené stavební praxe. Pokládal za nutné zavést do procesu církevní výstavby prvky moderního plánování. V otázce vzhledu a uspořádání sboru se klonil k pouhému stanovení zásad, jimiž se mají architekti řídit ve své tvưrčí práci, a stavěl se kriticky k jejich přílišné konkretizaci.

V myšlení Miroslava Kouřila se objevují ideje a důrazy, s nimiž se setkáváme v pojetí moderní liturgické architektury i jejích iniciátorů ve 20. a 30. letech minulého století. Zdá se, že k nim dospěl spíše nezávisle sdílením stejných nebo podobných obecných zásad architektonické moderny, jmenovitě funkcionalismu. Původní je zcela jistě přesvědčení, že tyto zásady moderní liturgické architektury se mají stát pro Církev československou všeobecnou normou.

Velmi plasticky Kouřilův přístup k otázce liturgického prostoru ukazuje, že Liturgie Karla Farského byla ve 30. letech nahlížena a přijímána především jako dílo slovesně-hudební. Tomu odpovídalo spíše statické pojetí liturgického prostoru jako koncertní síně, která rovněž nepředpokládá dění, pohyb či dynamickou akci.

\section{Husitská teologická fakulta Univerzity Karlovy Katedra praktické teologie Pacovská 350/4 \\ 14021 Praha 4 E-mail: pavel.kolar@htf.cuni.cz}

\footnotetext{
${ }^{64}$ Srov. J. E. Koula. Soutěž na sbor církve českomoravské v Praze-Záběhlicích. Architektura: spojené časopisy Stavba, Stavitel, Styl 4, 1 (1942), s. 97-102, zde s. 101-102. Srov. také Arnošt Hošek, Miroslav Kouřil, Josef Raban. Ideový projekt Janáčkovy sině [201804-10] https://www.archiweb.cz/b/ideovy-projekt-janackovy-sine.
} 